\title{
Buddhism and Law
}

\author{
Sandip K. Singh \\ (Director Counseling Cell) \\ Bharatiya Vidhi Sansthan, Mumbai) \\ $\mathrm{Mb}: 08090070445$ \\ Dated: 16-02-2013
}

\begin{abstract}
The whole message of Buddhism is to urge upon us that we have been born to die in the past but we need not be born to die in future. There is a hope in the thought that some of the ideologies contending for supremacy today also do not think that ideological disputes cannot be settled by war. It has become clear that physiological and biochemical studies alone cannot give us comprehensive account of nature and potentialities of man. We need a new philosophy of man based on his achievements in all cultural, traditions which can form a subject of further exploration and experimental study. Laws are meant for men and extent to which the tools of law can be utilized or dispensed with depends on what man really is and what he can make of himself.
\end{abstract}

\section{Keywords}

Buddhism, law, Buddhism and law, Buddhist jurisprudence, India, Buddhism

Law becomes meaningful only on the basis of the ethics, because law as an instrument for achieving certain ends. Ethics, in turn, receive its validity from the theory of reality. The theory of reality in turn becomes significant on the background of a theory of knowledge. This is also a fact that law is concerned with the behaviour of a "person' or a group of person living in society within a sate or nation. Buddhist a system of middle path also upholds the theory known as Saugata Simha Nada, i.e. Sarvam dukkham, Sarvamksanikam, Sarvamanatman.

There is no Gods who has created the world. There is no 'person' in the sense of a metaphysical entity. In Buddhism, the ruling class becomes the community of the people who have equal rights and delegate their power to the state. Hear the concept of dharma (righteousness) is superior and anterior to a Personal God. In such a context the idea that the law should safeguard the rights of the weak is radically transformed. In Buddhism the 'person' is a specific psycho-physical process who maintains a relative individuality, because of its specific Vasana of performed deeds, within cosmic existence, despite the lack of a persisting substratum.

Consequently, if the freedom of volitional acts, karmic correlations and serial individuality is denied, moral responsibility would be a meaningless concept. In Buddhism person is a pudgala or a bearer of a burden (Bharahara) of the five constituents (rupa, vedana, sajna, samskara and Vijanana), having variation owing to differences in the impact of his environment, heredity and samskaric history of psychic past going back into prior lives. The belief in the inherent goodness of man led Buddhism to uphold that if man was educated in right and wrong, he is likely to be law-abiding. This belief further led Buddhism to the abolition of capital punishment and some times even corporeal punishment based on reformatory theory of punishment, only secondarily deterrent. 
This is also a significant fact that in contract to command theory, Buddhism thinks it desirable to base one's conduct on the ten kushala karmas and allows a person to decide voluntarily the percepts in accordance with self -interest and expediency. Though there is a place for sanctions in law in Buddhism, the law is based on consent resulting from understanding, friendliness and mutual interest. Therefore we find the talks of three (attãdhipateyya), respect for dictates of our conscience, respect for public opinion and respect for righteousness or Dhamma in Buddhist texts. But Buddhism is not unmindful of the fact that there are class of people who withdraw themselves from crime due to fear of punishment in his life.

Thus through the goal of Buddhism is a state in which there is freedom from fear, it recognizes the importance of cultivating essence of moral shame and moral dread in the initial stage of one's moral development.

Being a staunch believing system in righteousness, the Buddhist ethics is based on two axes. In words of K.N. JAYATILLEKE, "While one axis of ethical action turned round the notion of perfectibility, the other revolves round the utilitarian and humanistic conception of good of mankind". The two ends are not variances with each other, because the means adopted for attaining these ends are same, namely selfishness (Tyaga), friendliness (Maitri) and wisdom (Prajna). As a result Buddhism adheres to the views that the sate must be founded on the principle of love and understanding rather than on fear of punishment, though fear also plays a minor role. The implication of the above fact is that the penal laws must be based on a primarily reformatory and only secondarily deterrent theory of punishment. Buddhism does not for our retributive theory.

It is said that Buddhism upholds a theory of natural laws. In this context the following three facts are significant to be noted-

Firstly it is significant to note that the theory of natural law propounded in Buddhism by virtue of the fact that karmic correlations are a special instance of causal correlations in nature, which is an ordered system. Therefore Buddhist texts say that morally good, bad actions and actions of mixed of mix nature are followed respectively by pleasant and unpleasant consequences and consequances of mixed nature. So an individual must avoid evil and do good. Buddhism also urges people that because he has a potency of a would be Boddhisattva, he should be ready to return good for evil and dedicate even one's life for the good of each and every one. Not only on human plane but even on. The state plane this enlightened attitude is to be reflected even in penal laws.

Consequently wrongdoers is to be punished with an attitude of reform in his life and secondly for deterrent reason. Thus it is clear that Buddhism will appose the views of Dr. Zurcher that "the concept of inexorable justice, the existence of the 'Natural law' of karma 'is' the cosmic counterpart of worldly government". We know that the natural law of karma is a casual law in Buddhism and therefore should not be identified with jus naturale, which is secular law in the juridical sense.

Secondly, Buddhism accept a natural law theory in recognizing that man's conscience is generally aware of right and wrong even though conscience is admitted to be sometimes fallible: In the Anumana (inference) Sutta, the principle is laid down that one should not do unto others what one 
does not wish others to do unto oneself.

Thirdly, Buddhism upholds a natural law theory in the sense that it puts forward a social contract theory of the origin of the state and all that it implies.

In Conclusion we can safely state that the entire message of Buddhism is to support upon us that we have been born to expire in the past but we need not be born to die in future. There is a hope in the consideration that a few of the ideologies contending for superiority today also do not think that ideological disputes cannot be settled by conflict. It has grow to be apparent that physiological and biochemical studies unaided cannot give us wide-ranging explanation of character and potentialities of man. We need a new philosophy of man based on his achievements in all artistic, civilization which can form a topic of further investigation and experimental study. Laws are meant for men and extent to which the tools of law can be utilized or dispensed by depends on what man actually is and what he know how to make of himself.

$* * * * * * * * * * * * * * * * * * * * * * *$

International Conference on "Buddhist Jurisprudence And The Constitution" Held on 15-15 feb 2013 at Sarnath organised By MAHA BODHI SOCIETY OF INDIA, SARNATH CENTRE, VARANASI-221007 (UP) INDIA) in Collaboration With Central Tibetan University, Sarnath, Varanasi and Bharativa Vidhi Sansthan, Mumbai 